\title{
Beyond Two Decades of Social Transition in Ukraine: The Underestimated Power of Agency in Transition Research ${ }^{1}$
}

\author{
OLGA OLEI NI KOVA \\ University of Sydney, Australia \\ ooleinikova@gmail.com
}

\begin{abstract}
The purpose of this article is twofold. Firstly it explains the process by which democratic social transformations are realised in post-Soviet Ukraine; and secondly it introduces models describing the lifecourse strategies that Ukrainians utilise in facing the uncertainties of a society in transition. By analyzing and dissecting the individual's ways of dealing with systemic structural changes in the economic, political and social spheres this paper demonstrates how the sociology of life strategies can be applied to the specifics of post-Soviet Ukraine. Particularly, by drawing on mainstream post-Soviet scholarship and statistical data, the life pathways of Ukrainians are observed to be distinctly polarised. Agents adopt one of two opposing life strategies: one dynamic, risk-taking and future-oriented "achievement strategies" (or "creation strategies"), which are open to mobility; and the other conservative, risk-minimizing and survival-oriented "survival strategies" and "strategies of adaptation" that are less conducive to any type of change. Focusing on existing problems of a continuously fragile internal political and economic stability in Ukraine which have threatened to further delay the incorporation of Ukraine into the democratically advanced and developed West, this article puts forward the idea that the proliferation of life strategy type can determine the vector of development of the whole society, giving insight into the circular relationship between social transformations and actions of individuals in conditions of social change.
\end{abstract}

Key Words: post-Soviet Ukraine, Democratic Transition, Structure-Agency Perspective, Life Strategy, Achievement Strategies, Survival Strategies.

\section{Introduction}

This new civilization brings with it new family styles; changed ways of working, loving, and living; a new economy; new political conflicts. Millions are already attuning their lives to the rhythms of tomorrow. Others, terrified of the future, are engaged in a

\footnotetext{
${ }^{1}$ Acknowledgement: The draft version of this article was presented at the "Ukraine: Language, Culture, Identity" conference, Mykola Zerov Centre for Ukrainian Studies at Monash University, 15-16 February, 2013. Based on the valuable feedback and inspiring conference discussions with Australian and Ukrainian scholars the paper received its current context. First and foremost, I would like to thank Dr. Catriona Elder, my supervisor, for her support and encouragement. She kindly read my paper, offered invaluable amendments and generally guided my thinking. I am thankful to Dr Halyna Koscharsky and Professor Marko Pavlyshyn whose comments helped to identify theoretical and methodological gaps in my conference paper. Also, I would like to thank Navid Tofighian for detailed advice on grammar and article organization. 
desperate, futile flight into the past and are trying to restore the dying world that gave them birth." 2

The era of democratisation and individualisation as the new social reality, which is believed to be the dominant trend in current social processes in the advanced and democratically developed West, ${ }^{3}$ has developed differently in the post-Soviet Ukraine. The fact that the former Soviet countries have shifted to democratic political regimes, and their often related capitalist economic systems, in their special way has often been overshadowed by domestic factors and is still waiting to receive proper attention in the mainstream literature. Ukraine's attempts to create market economy have proved problematic. As with other post-Soviet states, the reform process of the early 1990s saw a rapid economic contraction, leaving many facing economic uncertainties. Therefore, democratization and capitalism, which in many Western capitalist democracies went hand in hand, have been completely disentangled by the emerged informal economy in contemporary Ukraine and related practices, which people operated out of necessity due to low wage and pension rates and high levels of corruption. Therefore, Ukrainian capitalism differs from its original, neoliberal design and has been modified by the processes of adaptation and resistance of the people involved. The outcomes of transformation today can be defined as a "clan liberalization" of the economy and the "bureaucratic democratization" of society.

By challenging the "individualization hypothesis," which assumes that in the modern globalised world life-chances and social actions are increasingly shaped by personal biographies rather than social structures, this article puts new wind into the sails of the idea that the interplay of structure and agency is more relevant, rather than the focus only on either the individual or structure, for the understanding of social transformations that took place within democratic reforms in post-Soviet Ukraine. The existing social structures continue to have a significant bearing on the formation of life trajectories of individuals. However, there is an emerging interest, in terms of the generally held concerns of sociologists and policy makers with the strategic approach to the development vector, in the life patterns of individuals in the process of social transition, mostly affected by both institutional change and the individual's response to change. Being the preeminent indicator of the success or failure of current democratization processes a focus on the individual lives of the agents of social change, their life trajectories and their potential to transform socioeconomic structure, they are worthy of deeper investigation.

This descriptive and analytical article is based on the circumstances of the past two decades within Ukraine after the collapse of the Soviet socialist system in 1991. Particular attention is paid to the investigation of: (1) the conditions and dynamics of changes in the socioeconomic and the political sphere of life of Ukrainian society during the first twenty-two years of independence; (2) people's reactions to the instability that marked this period and (3) their ways of adapting to systemic factors such as unequal distribution of power, information and opportunities which suggests a diversity of behavioral outcomes. Consequently, the analysis is driven by agent-structure-agent relations and suggests there is a circular relationship between social transformations and actions of individuals in conditions of social change.

\footnotetext{
2 A. Toffler, The Third Wave, Bantam Books, New York, 1980, p.25.

3 P. Sztompka, 'Cultural Trauma in Post-Communist Society', Sociological Research, No. 2, 2001, pp. 3-12; A. Toffler, The Third Wave, op. cit.; Z. Bauman, The Individualised Society, Cambridge, Polity, 2001. 
Oleinikova ANZJ ES 5(2)

After referring to some of the theoretical work on transition research that has emerged in the West from about the 1980s and since the 1990s in post-Soviet Eastern Europe, this article then takes a closer look at the theoretical traditions that explain the essence of post-Soviet democratic transition and emphasises the importance of the power of agency in social change. Then making its way from this macro analysis of social transformations to micro analysis of life strategies within the post-Soviet sociological perspective, this article conceptualises the notion of life strategy. It does this by dissecting the individuals' ways of dealing with structural changes using a series of surveys that map some of the key "strategies" or responses to the transition. In the attempt to make the case for the need for a different approach from the one imported from the West to the post-Soviet transition paradigm, the article's final section illustrates relevant strategy models and links them to the key structural issues that affect Ukrainian population and form their relevant behavioral models. Using the general survey data about how people describe their lives in transition, not the data on what people are actually doing, the article concludes with the examination of the ways people act as agents, with an emphasis on what happens when the agency is added to the dominant (Western) model of transition.

\section{Theorising post-Socialist Democratic Transition: from Structuralism to an Agent-Structure Approach}

"There is no democracy without democratically minded and competent citizens, there is no capitalism without trained entrepreneurs, there is no open exchange of ideas without interested stakeholders ... Therefore, cultural change and the consequent change in mindset, attitudes and motivations of social actors - a necessary component of institutional reforms."4

Contemporary democratic transition in the post-socialist societies has been characterised as being determined by social disintegration, shifts in values and the formation of a new structure of social relations. Before presenting post-Soviet life strategy studies, some remarks on the historical context and theoretical understanding of post-socialist transformation are necessary. The notion of post-socialism emerges within the political sciences and sociology in the context of the debate on the democratization and marketization of former socialist states.

In order to understand the debate on post-socialists transformation better, it is worthwhile reviewing some of the features of the Ukrainian case in the context of the existent theories and interchanging cycles of structure-centered and agent-centered theoretical paradigms explaining post-Soviet regime change. The transformation processes within Ukrainian society: the transition from authoritarianism towards democratic governance and in the recent years a roll-back of these changes to the active promotion of authoritarian practices by regime, market reforms and nationalist revival have significantly influenced the behaviour of Ukrainians. Effects have been especially noticeable in their attempts, on one hand, to adapt and tolerate the changing conditions, while on the other to try to use changes in their favour.

Along with freedom of choice and a rise in independent decision-making by individuals, democratic reforms implemented in Ukraine since 1991 have brought greater risk and more responsibility in decision-making. This has led to the emergence of a deep differentiation in citizens' wage levels and career prospects. Twenty years of steady promotion of democratic reforms and resistance to the structural legacies of the past have not yielded good results in

4 Sztompka op.cit, p. 4. 
terms of democracy, but instead have led only to semi-democratic forms of decision-making at the state level along with the emergence of a sharp socioeconomic differentiation among social groups. Consequently, the growing disenchantment with democratic promotion in Ukraine as well as in other young democracies has led to a widespread skepticism to this form of development. Various studies ${ }^{5}$ began to interrogate whether the democratic transition has had any positive outcomes at all. A question posed here is whether there will be a third even more intensive wave of democratization in the twenty first century? Irrespective of what happens in the future, in the current transition paradigm there is a need for a different approach to studying what has happened in Ukraine, one which would widen our understanding of societies in transition in terms of "the deeper, spontaneous shifts typical for social and individual consciousness that find expression primarily in the transformation of the value system, in the formation of new individual life strategies." 6 This paper brings to the forefront the research gap on agency and its underestimated role in the context of the postSoviet social change, which was influenced by the formation of Western theories and cycles of theoretical paradigms emphasizing the structure. On the general theoretical level the goal of this paper is to provide a better theoretical understanding of the interplay between the "agential" and "structural" sides of life strategies of individuals coming from a post-Socialist country with changing socio-economic reality.

Retrospective analysis of transition research since 1980s shows that within the transition paradigm, popular in Eastern and Western European social science, scholars have found that the incorporation of such theoretical concepts as human agency and structural factors bear more fruit in demonstrating empirically and theoretically the long-term effects of social change at individual and collective levels, and their residual effects on structural transformations. The works of Merkel7 ${ }^{7}$ Carothers ${ }^{8}$, Ottaway ${ }^{9}$, Levitsky \& Way ${ }^{10}$ and Nathan ${ }^{11}$ are indicative not only of the shift in the focus of transition research from actorcentered theoretical paradigm to structuralism shifts in the perception of democratic changes in new post-Soviet democracies from an optimistic outlook in the early 1990s to pessimistic attitudes to democracy that have been continually multiplying since the 2000s. At the beginning of the 1980s Western research on transition was driven by the agentcentered perspective propagated specifically in the writings of O’Donnell \& Schmitter, ${ }^{12}$ while in Eastern Europe at that time no one could ever think of a possible future shift to democracy that would actually necessitate this type of research on transition. In the work of O'Donnell \& Schmitter ${ }^{13}$ all the discussion about the factors for success or failure of transitions revolved around the ruling elite as the driving force in initiating shifts on all levels. The socioeconomic

\footnotetext{
${ }^{5}$ T. Carothers, Aiding democracy abroad - the learning curve, Washington, DC, Carnegie Endowment for International Peace, 1999; S. Knack, 'Does Foreign Aid Promote Democracy?,' International Studies Quarterly, Vol. 48, No.1, 2004, pp. 251- 266; P. Burnell, 'Does international democracy promotion work?,' DIE Discussion Paper, No.17, 2007; W. Merkel, Systemtransformation. Eine Einfuhrung in die Theorie und Empirie der Transformationsforschung (2., u“ berarb. u. erwe. Aufl.), Wiesbaden, VS Verlag für Sozialwissenschaften, 2010.

6 N.R. Naumova, 'Individual Life Strategy in a Transitional Society,' J ournal of Sociology, No.2, 1995, p.7.

${ }^{7}$ W. Merkel, 'Embedded and Defective Democracies' in A. Croissant \&W. Merkel (eds.) Consolidated or Defective Democracy? Problems of Regime Change, London, Taylor \& Francis, 2004; W. Merkel, Systemtransformation. Eine Einfuhrung in die Theorie und Empirie der Transformationsforschung (2., u “berarb. u. erwe. Aufl.), Wiesbaden, VS Verlag für Sozialwissenschaften, 2010.

8 T. Carothers, 'The End of the Transition Paradigm,' J ournal of Democracy, Vol.13, No.1, 2002, pp.5- 21.

${ }_{9}$ M. Ottaway, 'Promoting Democracy after Conflict: the Difficult Choices,' International Studies Perspectives, Vol.4, No.3, 2003, pp. 314- 322.

10 S. Levitsky \& L.A. Way, 'The Rise of Competitive Authoritarianism,' J ournal of Democracy, Vol. 13, No. 2, 2002 , pp. 51- 65.

${ }^{11}$ A.J . Nathan, 'Authoritarian Resilience,' J ournal of Democracy, Vol. 14, No. 1, 2003, pp. 6 - 17.

12 G. O’Donnell \& P.S. Schmitter, Transitions from Authoritarian Rule. Tentative Conclusions about Uncertain Democracies, Baltimore, MD, J ohns Hopkins University Press, 1986.

13 Ibid. 
Oleinikova ANZJ ES 5(2)

preconditions where accepted as no longer relevant for transition research. ${ }^{14}$ The main focus of theoretical explanations lay with agency: it was believed that any type of transformation would be possible only if the relevant elite groups (ruling and opposition) could agree on the common ways of implementing democracy. However, O’Donnell \& Schmitter do not deny the importance of structures in regime change. At that time empirical transition research dealt primarily with successful cases of transition. In other words, this optimism for democracy was dependent on the voluntaristic human action approach and rejection of socioeconomically and politically structural "requisites of democracy."15 Since the 1990s the agency perspective has faced a wave of "structuralism and the wave of pessimism." 16 It was argued that the power of political elites was overestimated and another approach was developed that suggested that democracy can be promoted, supported or even imposed from the outside began to dominate. ${ }^{17}$ Action theory had shown itself to be deficient in its analysis of political and socioeconomic system transformations.

This wave of structuralism in transition research coincides with the expansion of democracy following the collapse of communism in 1989-90. Therefore, post-Soviet Eastern European societies began to produce scholarly works only relatively recently, after 1992, when there finally appeared a real need to understand the consequences of reforms and transformations. The first research on transition in post-communist countries was strongly influenced by the existing research of the Western tradition and so determined by the dominant structural paradigm. As in early 1950-1960s, structural factors such as the degree of development of national economies, the power of social classes, the autonomy of the state and the efficiency of its bureaucracy once again became central to research on system transformations. ${ }^{18}$ Pye $^{19}$ and Lipset et al. ${ }^{20}$ proclaimed the renaissance of modernization theory ${ }^{21}$ in the post-Soviet democratization theoretical discourse. Zaslavskaya, a Russian scholar, under the influence of Roxborough $^{22}$, defines modernization as a "growth of capacity for social transformations." 23 Within the structural tradition Zaslavskaya ${ }^{24}$ suggests the typical trend for post-Soviet scholarship of late 1990s to define social transformation as "gradual, not associated with the change of the ruling elite, but at the same time a radical and a rapid change in the social nature or societal type of society determined by the external factors and internal necessities." Accordingly, the initial interests of the first post-communist research was on the macro structural forces and mechanisms of transition and their impact on the processes of social differentiation within the society, as well as the changes in personal characteristics of the population.

Subsequently, the post-Soviet studies on transitions have been the opposite of earlier transition research. From the late 1990s to the late 2000s they shifted focus from the

\footnotetext{
14 Merkel, 2010, Ibid.

15 S.M. Lipset, 'Some Social Requisites of Democracy: Economic Development and Political Legitimacy,' American Political Science Review, Vol. 53, No. 1, 1951, pp. 69- 105.

16 Merkel, 2010 Ibid, p.19.

17 Merkel, 2010 Ibid, p. 436.

18 Merkel, 2010 Ibid.

${ }^{19}$ L.W. Pye, 'Political Science and the Crisis of Authoritarianism,' American Political Science Review, Vol. 84, No. 1, 1990, pp. 3- 19.

20 S.M. Lipset, K. Seong \&J .C. Torres, 'A Comparative Analysis of the Social Requisites of Democracy,' International J ournal of Science, Vol. 45, No. 2, 1993, pp. 155- 176.

${ }^{21}$ Merkel, 2010 Ibid.

22 I. Roxborough, 'Modernization Theory Revisited,' Comparative Studies in Society and History, Vol. 30, No. 4, 1988, pp. 753-761.

23 T.I. Zaslavskaya \&V.A.Yadov, Report on the opening of III Russian Sociological Congress, October 21, 2008, available at <http:// www.polit.ru/article/ 2008/ 10/29/soctransformations/>, accessed 30 November 2013.

24 I.T. Zaslavkaya, Transformation Process in Russia: Socio-Structural Aspect' in I.T. Zaslavkaya \&Z.I. Kalugina (eds) Social Trajectory of the Reforming Russia: Research of Novosibirsk School of Economics and Sociology, Novosibirsk, Siberian enterprise RAS (8), 1999, p. 150. 
structuralist perspective (imposed by the popular Western structuralism trend in transition research in early 1990s) and went back to an agent-centered perspective in combination with a structural paradigm. ${ }^{25}$ Since the beginning of the new century, the skepticism about the continuous successes of democratization has become apparent in social and political science discourses in the West as well as in the post-Soviet space. Parallel to the theoretical revisions that took place, there has been a growing disenchantment with the concept of promoting democracy. After two decades of endorsing democracy in post-Soviet states, the practical results have shown that what was necessary for the successful democratic transition for countries of the West, where structural factors and path dependency were taken seriously, was no longer applicable for post-Soviet Eastern European countries. In these countries the call for democratization had led to a sudden resistance in the form of an active promotion of authoritarian practices in the actual regime, which influenced the formation of semidemocracies or semi-autocracies. Given the current economic, political and social uncertainty in many former Soviet countries, it is hard to say whether current theoretical and empirical research can suggest any kind of resolution to the stagnation of these democracies, nor can they provide any explanations to what went wrong in post-Soviet transition processes and why the whole world still questions whether there is a democracy in Ukraine, Russia or Belorussia. However, all post-Soviet scholars agree that there is a need for the creation of a specific theory explaining post-communists transformations which have not followed the pattern imagined by scholars in the West.

From 1980 to 1990, as a result of such discussions, Eastern European scholars have made significant achievements in the empirical description and the conceptualization of postcommunist transformations. ${ }^{26}$ Subsequently, "agent-structure problem" has emerged as the main theoretical model in post-Soviet transition research. Post-Soviet scholars started to develop their own ideas of the transition. They suggested that the most theoretically efficient ways to approach the issue was to determine the interrelation between the different components of the transformation processes: (1) targeted reforms of basic institutions; (2) semi-natural changes in the social structure and (3) poorly managed change of human potential (agency). ${ }^{27}$ It became obvious that in order to find out the most common (and therefore most important) patterns of transformation of these modern societies, it was necessary to study three interrelated components: (1) the dynamics of the institutional system (structure), (2) social group structure and (3) human capacity (agents). The study of the interrelation of these elements is relatively rare, but a movement in this direction has been observed. Recently there have been studies of interrelated changes in the institutional system and the social structure: in social structure and human potential, and, only rarely, in the institutional system and the human agency. There are examples of a comprehensive study of agent-structure components in the works based on Russian experience of post-socialist societal transformation and strategic development. ${ }^{28}$ A number of Ukrainian scholars have

${ }^{25}$ S.S. Babenko, 'Life Strategies and Social Practices: Sociocultural Potential of the Post-Soviet Society Transformation,' Methodology, theory and practice of sociological analysis of society: a collection of scientific papers of Kharkov National University, 2002, pp. 57-64; O.D. Kutsenko \& S.S. Babenko, Changing Diversity: Vectors, Dimensions and Content of PostCommunist Transformation, Kharkiv, V.N.Karazin Kharkiv National University Publisher, 2004; I.T. Zaslavkaya,

Transformation Process in Russia: Socio-Structural Aspect' in I.T. Zaslavkaya \&Z.I. Kalugina (eds) Social Trajectory of the Reforming Russia: Research of Novosibirsk School of Economics and Sociology, Novosibirsk, Siberian enterprise RAS (8), 1999, pp. 149-167.

${ }^{26}$ O.D. Kutsenko, Post-communists Transformation: Vectors, Directions, Content, Kharkov, Karazin Kharkiv National University Publisher, 2004.

27 T.I. Zaslavskaya \& V.A.Yadov Ibid.

${ }^{28}$ T.M. Maleeva, 'Social Policy and Social Strata in Contemporary Russia: What has Russia come to?' in T.I. Zaslavskaya (eds) Results of Societal Transformation, Moscow School of Social and Economic Sciences, Intercentre, 2003; T.I. Zaslavskaya, Societal Transformation of Russian Society: Agency-Structure Framework, M: Delo, 2003; T.I. Zaslavskaya, The 
Oleinikova ANZJ ES 5(2)

contributed to the identification of the current state of post-Soviet transitions and its impact on agents. ${ }^{29}$ In particular, post-Soviet Ukrainian scholarship is now centered on the study of post-Soviet life style peculiarities, the structural determinants of life chances and

opportunities, social transformation through the lens of identity shifts, phases and ways of achieving systemic transformations based on similarities and differences to the former state socialism.

However, Eastern European as well as Western studies focus primarily on the group, the role of the individual as an agent of social change is still outside the remit of most scholarly attention. The problem of the individual subject is affected mainly through the psychological derivatives of the social structure and group identity. At the same time the analysis of the dichotomy of the individual and society in the history of sociological thought has proved that no matter which conceptual framework theorists follow, they cannot ignore the role of human agency in the creation of the social world.

The understanding of the transformations in Ukraine as applied in this article defines a system's transformation, according to Mach30 as: "the interaction of organizational plans, oriented to the creation of collective identity of newly emerging system and the rules functioning of institutions it consists of, and individual plans, oriented to the creation of new individual identities and new rules of individual functioning." This approach defines the fact that capitalism in Ukraine differs from its original, neoliberal design and has been modified by the processes of adaptation and resistance of the people involved. However, contrary to a tendency to "underestimate the role of agents in shaping institutional change in novel and historically contingent ways," 31 the perspective applied in this reminder of the article explicitly concentrates on a combination of focus on social actors, who can draw from all available resources (including those deriving from their socialist past) in their attempts to cope with changing social reality ${ }^{32}$ and the structural determinants of social actions. It acknowledges the relative autonomy of the structural and cultural properties of a social system from the agency of the people involved. It is argued that the actions of social actors can be a better indicator of social, political and economic changes in the institutional structure and that individuals' life practices are just as important as structural parameters in determining individuals' wellbeing. ${ }^{33}$ In this context, the reconstruction of the new socio-economic system

Difficulties of the Social Structure Development in Russian Society', Integrity of Eurasia, No. 3, 2004, pp. 191 - 201; T.I. Zaslavskaya, 'Modern Russian Society: Challenges and Prospects', Public Sciences and Modernity, Vol. 5, No.6, 2004, pp.5 19; R.I. Kapelushnykov, Notes on the domestic human capital', Domestic Notes, Vol.37. No.3, 2007; M.A. Shabanova, 'Social stratification and freedom', J ournal of Sociology, No. 4., 2007, pp. 48-63.

29 V.S. Bakirov, 'The post-Soviet life: Ukrainian Features' in O.D. Kutsenko (eds.) Post-Communist Transformation: Vectors, maintenance, measurement, V.N.Karazin Kharkiv National University Publisher, 2004, pp. 227-242; S.O. Makeev, The Structural Rational and Modern Society, Kyiv: Institute of Sociology NASU, 2006; S.S. Babenko, 'Social Mechanism of PostSoviet Transformation: Agency-Structural Perspective' in O.D.Kutsenko \& S.S.Babenko (eds) Changing Diversity: Vectors, Dimensions and Content of Post-Communist Transformation, V.N.Karazin Kharkiv National University Publisher, 2004, pp. 218-239; O.D. Kutsenko, Post-communists Transformation: Vectors, Directions, Content, Kharkov: Karazin Kharkiv National University Publisher, 2004; O.D. Kutsenko, 'Ukraine in Transformation Processes: Quo vadis?, Sociology: Theory, Methods and Marketing, No.1, 2007, pp. 18-32; E.I. Golovakha, 'Main Milestones and Trends in Transformation of Ukrainian Society: from the "perebydova" to the "Orange Revolution,"' Sociology: Theory, Methods, Marketing, No. 3, 2006, pp. 32-51; S. Kataev, Transformation of Modern Ukrainian Society: Postmodern Context', Human and Politics, No. 3, 1999, pp. 29-32.

30 B.W. Mach, Transformation ustrojowa a mentalne dziedzictwo socializmu [System Transformation and the Mental Legacy of Socialism], Warszawa: Wydawnictwo ISP PAN, 1998, p. 32.

${ }^{31}$ G. Eyal, E. Townsley and E. Szelenyi, Making Capitalism without Capitalists: The New Ruling Elites in Eastern Europe,

London, New York, Verso, 2000 [1998], p. 40.

32 Mach Ibid.

${ }^{33}$ C. Whelan \& B. Maotre, Measuring Material Deprivation in the Enlarged European Union, Dublin, Economic and Social Research Institute, 2008. 
is not merely a description of the background data, but also an element of the theoretical understanding of the research field.

The remainder of the article will focus on the under researched role of the citizens of Ukraine as agents, specifically the individual strategies they deploy to confront the consequences of structural transition. By means of the analysis of up-to-date publications, statistical data from different surveys, as well as by focusing on the variety of ways of conceptualizing and interpreting life strategies in the post-Soviet scholarship, the following section suggests a broader understanding of life strategy as a factor affecting post-Soviet transition.

\section{Conceptualising Life Strategy: post-Soviet Sociological Perspective}

As Morgan remarked, one of the main merits of studying life strategies is the analysis of "the complex dance between agency and structure."34 If strategies are developed in conditions of severe constrains, their study can reveal how social structures can influence agents' actions as well as how social agents attempt to overcome structurally set limitations. ${ }^{35}$ The notion of life strategy is used in this article as an analytical tool to investigate ways of coping with social change.

The notion of life strategy refers to the most complex and integral manifestation of a person's life. It expresses the logic of the life-world of individuals, their aspirations for the future and the ability to change their own lives in accordance with the challenges and demands of the present and the future. In sociology, strategies are usually related to the pursuing of conscious, rationally chosen, long-term planned goal. ${ }^{36}$ Individual life strategies are also among the most under studied phenomena and still lack a clear and concise definition and research methodology. This concept is especially vague when it comes to the understanding of the role that social structures play in life strategy formation and implementation presented during the current transition stage of post-Soviet Ukraine. Therefore, it is necessary first to look more closely at the post-Soviet ways of theorising life strategies in order to justify the stance proposed in this article.

Resnick and Resnick, the prominent scholars in the field of life strategy studies, provide several definitions for this phenomenon. On the one hand, they believe that individual life strategy can be seen as "symbolically mediated and beyond conscious limits ideal formation, which is realised in human behavior, its priorities and guidelines." 37 In another outstanding work on life strategies, it is argued that life strategy is a "dynamic system of long-term orientation of the individual, including a change (formation) in accordance with a specific plan and given terms of socio-cultural development."38 The work of Abulkhanova-Slavskaya39 is fundamental to understanding the nature of life strategy. This work is the basis for all modern developments in the field of life strategy studies in post-Soviet scholarship. She approaches the concept of "life strategy" by assessing the social and psychological maturity of personality, which, she argues, manifests itself in the ability of an individual to combine their status, age capabilities, personal aspirations with the claims and requirements of the society. The ability to make the connection between these variables constitutes what the author

${ }^{34}$ D.H.J . Morgan, 'Strategies and Sociologists: a Comment on Crow,' Sociology, Vol. 23, No. 1, 1989, p. 26.

${ }^{35} \mathrm{G}$. Crow, The use of the concept of strategy in recent sociological literature,' Sociology, Vol. 23, No. 1, 1989, p.19.

${ }^{36}$ Crow Ibid, p. 2.

${ }^{37}$ T.E. Resnick and U.M. Resnick, 'Individual Life Orientation: Analysis and Advice,' Sociological Research, 1996, p. 111.

38 U.M. Resnick and E.A. Smirnov, Life Strategies of Individual (Experience of Complex Analysis), Moscow, 2002, p. 99.

39 K.A. Abulkhanova-Slavskaya, Strategies of Life, Moscow: Mysl, 2001.

52 
Oleinikova ANZJ ES 5(2)

defines as an individual life strategy. More precisely, the author considers a life strategy to reflect the ability of individuals to interweave their identity with their living conditions. An analysis of the existing conceptual formulations of "strategy" indicates that in the current scholarly literature the problem of how some external means allow for the achievement of a certain goal is yet to be solved. This explains the present misunderstanding and confusion regarding the relationship between the individual's strategic goals and their means of achieving them: some authors give priority to goals, while others consider the importance of resources, rules or standards of separate actions in the first place.

The concept of life strategy was brought to Soviet sociology in the 1960s and became a popular field of study in the post-Soviet scholarly period. Its relevance was driven by the need to explain the social factors of the crisis on social values that emerged in the post-soviet transitional stage, as well as, the population's reaction to the ongoing transition. Previously, sociologists studying the transformation processes would interpret the processes of social change in terms of historically defined trajectories referring to the analysis of results, not the processes. Since the 1990s scholars have had the chance to capture fluctuations on all the levels of the ongoing process. This becomes possible in times of a regime change, when the relationship between society and the individual gains tangible features of mutual determination. Subsequently, the specifics of the post-Soviet life strategy studies lies in its research subjects, primarily: (1) the state of collective consciousness, (2) public sentiments, (3) the extent of the readiness of the population to accept the new social order and (4) willingness to adapt to the situation of changes.

Since the early 1990s the analysis of post-Soviet social reality has spawned a series of widely used terms, such as: "survival strategies" and "adaptation strategies," as opposed to the notion of "strategies for achievement. "Zaslavskaya identified three types of transformational activity: (1) targeted reforming activity, (2) mass social innovation activity, and (3) reactivelyadaptive behaviour. ${ }^{40}$ On this basis she defines four classes of strategies: achievement, adaptation, regression and destruction. In the definition of the concept of adaptation strategies, the author addresses the notion of survival: "The basis of adaptation strategies is a commitment to social survival, maintaining the same or at least a minimum acceptable social status. It is an important function to increase the adaptability of people to the difficult conditions of a changing world." 41 Ukrainian scholars, Zlobina and Tikhonovych, in the late 90s built a model of life strategies based on a dichotomy: survival strategy as the opposite to strategy of life creation. He argues that the basis of the life strategy is the level of adaptation: from the voluntary "successful and positive" to "forced" adaptation. ${ }^{42}$ Belyaeva43 (2000) supports the ideas of Zlobina and Tikhonovich by proposing that the level of adaptation to the ongoing transformation is the strongest indicator of real social stratification - class formation and division. Therefore, she identifies three typical groups of adaptation: "successful," "adaptable" and "survival." It was argued that the "successful" group members benefited from the reforms and assessed their financial situation as "better than by others" (according to VCIOM44 in 2000 the percentage of such people in post-Soviet Russia was 6\%). Those in the group that "adapted" were assessed as not winning, but they also did not lose from reforms.

\footnotetext{
40 Zaslavkaya, 1999 Ibid, p. 152.

${ }^{41}$ T.I. Zaslavskaya, 'Socio-Structural Aspect of the Russian society Transformation,' Sociological Research, Vol. 8, No. 3, 2001, p. 15.

42 O. Zlobina and V. Tikhonovich, Societal Crisis and Life Strategies of Individual, Kyiv, Stylos, 2001, pp. 85-85.

${ }^{43}$ L.A. Belyaeva, 'Strategies of Survival, Adaptation, Prosperity,' Sociological Studies, No. 6, 2001.

${ }^{44}$ Russian Public Opinion Research Center (VCIOM) - (before 1992 - All-Union) - the oldest Russian research organization, regularly conducting sociological and marketing research based on public opinion polls. Being established in 1987, today it is one of the largest Russian companies in this market. 
This group assessed their financials as "about the same as by others" (29.5\%). Those who were classified as "surviving", meaning they have lost from the reforms and had assessed their financial situation as "worse than others" made up $56.7 \%$ of the Russian population. ${ }^{45}$ These studies are particularly important for the determination of the basic socio-psychological and socio-cultural foundations of societal transformations, within the particular socio-cultural environment, which sets the parameters for the structuring of life strategies. Subsequently, in modern post-Soviet transition studies a common conceptual language that would allow one to adequately describe typical forms of life strategies at the structure-agency level of analysis needs to be developed. ${ }^{46}$

\section{Relevant Life Strategy Models of Dealing with Uncertainties}

In March, 2013 by Olena Zlobina, Head of the Department of Social Psychology, Institute of Sociology (NAS of Ukraine), reported that " $27 \%$ of Ukrainians apply adaptation strategies; $32 \%$ apply avoidance/ exclusion. Another 25\% have an indefinite life strategy."

${ }^{47}$ Referring to the data from "Ukrainian Society: Monitoring of Social Change"48, she also noted that recently the group of people using the strategy of avoidance/ exclusion is steadily decreasing - from $45 \%$ in 1997 to $32 \%$ in 2012 . There was also a noticeable decline in the group of Ukrainians figured as adapting - from 36\% in 2003 to 27\% in 2012. Meanwhile, a group of those who mastered the situation has doubled - from $8 \%$ to $16 \%^{49}$ and then remained quantitatively almost unchanged.

What do these figures tell us? Analyzing the data through Ukrainian transition research shows that 1992-1998 (especially 1992-1996) were the toughest years of radical social transformations and were characterised by anomie, deinstitutionalization and macro involution, and uncertainty in formation of a new social order. The prolonged systemic crisis that overtook Ukrainian society in the first decade of transition has affected the moral and psychological atmosphere in the country. There was a permanent decline in economic production and, consequently, a decline in overall people's well-being. A lifestyle of survival has become the norm for most of the population. Since salaries and pensions were extremely small, payments could only meet the basic and urgent needs for food, clothing and home maintenance. The people's main task was to manage their lives - that is to survive physically and help those who were dependent on them. All other needs - cultural, spiritual, recreational, and cognitive - were saved for the future.

Millions of people have been pushed out from their social niches. Yesterday's highly skilled workers: mechanics, technicians, designers, engineers, agronomists, veterinarians, employees of research institutes, teachers, doctors, artists, and scientists were made redundant. Their knowledge and experience was no longer in demand. Unable to see prospects within their country and not having confidence in their future and the future of their children, the

45 Belyaeva Ibid, p. 328.

${ }^{46}$ Babenko, 2004 Ibid, p. 8.

47 Daily Lviv, Online News, The fate of the state in the hands of 16\% Ukrainians', February 12, 2013, available at $<$ http:// dailylviv.com/ news/41310?fb>.

48 The "Ukrainian Society: Monitoring of Social Change" is an annual social project coordinated by the Institute of Sociology since 1992. It consists of survey with Ukrainian population with a sampling of about 1,800 respondents (aged over 18), and representative for such parameters as gender, age, education, region and type of settlement. Center "Socis"conducts the fieldwork.

49 Daily Lviv, op.cit. 
Oleinikova ANZJ ES 5(2)

Ukrainian population felt humiliated and depressed. Marginalization covered entire social groups. Members of these groups were pushed to the social margins.

A number of the educated populace having a high level of education, high qualifications and a broad general outlook found themselves in the position of beggars. Some of them went in "chelnoki" - to sell domestic products abroad and buy foreign goods to sell back home. The newly formed social environment demanded a change in life orientations, norms and values. Those principles by which people were brought up just did not work in new Ukraine and people did not know how to organise their lives in the new environment. Anomie - the socalled state of mind when the old social norms and values are not working, and the new have not yet formed, resulting in a kind of a normative value vacuum - has overtaken vast masses of the population. In the 1990s negative emotions dominated among the mainstream population. Many Ukrainians had experienced different social fears. People were especially afraid of unemployment, hunger, unpaid wages, rising prices and an increase in crime. According to the Institute of Sociology the number of people generally dissatisfied with their lives, increased from 45\% in 1992 to $70 \%$ in 1998.50

Data from sociological monitoring shows that in the first decade of independence in terms of family material well-being $46.6 \%$ of Ukrainians described themselves as "squalid" and "poor." 51 5.6\% of respondents rated their lives as "squalid," as the average monthly income per member of the family dropped to $96.4 \mathrm{hrn}$. If we take into account the details, there emerges a fairly bleak picture: 3.1\% of respondents often do not have money and food, they live by alms; $9.8 \%$ are starving - they do not have enough food, and only $2.0 \%$ of respondents have enough of everything they need, with sufficient extra to even make savings. Another $0.3 \%$ have abundant resources. 52

Consequently, the first two decades of independence turned out to be an extremely hard time for all population groups. This was reflected in the widespread use of strategies of exclusion/ avoidance, survival and an indefinite state of mind. Given the context of a rapidly changing and unstable economic and political environment, this led to a polarization of people into adopting two opposing strategies, one conservative, risk-minimizing and survivaloriented that is less conducive to change of any sort - "survival strategies," and the other dynamic, risk-taking and future-oriented - "achievement strategies," and thus open to mobility. The first strategy was initially adopted in response to the shocks of transition by a majority of households and individuals in Ukraine, yielding a decline in population mobility. Actually, in the first decades of social transition in Ukraine the achievement strategy was not relevant given the survival circumstance. Clearly, people are only able to strive for achievement and success if they are - "not being hungry," and have support in the form of economic, social and cultural capital. The vast majority of Ukrainians felt a lack of these things in the 1990s.

Modern scholarly literature (especially Ukrainian and Russian) typically distinguished only two models of life strategy: a strategy of achievement and a strategy of survival. It emphasised that in the former Soviet Union (especially among older age groups) it was the latter that dominated. Scholarship suggests that the achievement strategies, being dynamic, risk-taking, future-oriented and "creative," are typical for societies where individualism, free market economics and pluralism dominate. ${ }^{53}$ In today's Westernised societies the strategy to achieve

\footnotetext{
50 N.A. Shulga, Drift to the Side: Twenty Years of Social Change in Ukraine, Kyiv, Drukarnya "Biznespoligraf", 2011, p. 123.

${ }^{51}$ I.M. Prybytkova, 'Migrant Workers in the Social Hierarchy of the Ukrainian Society: Status Positions, Values, Life

Strategies, Life Style,' Sociology, No.4, 2003, pp. 156-167.

52 Ibid, pp. 110-112.

53 T.E. Resnick, 'Individual Life strategies,' Sociological Research, No. 12, 1995, pp. 100-105. 
success in life can be seen as the most popular one. The Ukrainian case, being representative of some other post-Soviet societies, demonstrates that post-independent Ukraine is not yet a purely individualistic, sovereign and wholly democratic society. It is still on its way to becoming a welfare and egalitarian state, where people are not struggling for survival but are strong enough to compete for achievement and success. Likewise, life strategies of adaptation and survival are most prevalent in traditional and crisis societies. ${ }^{54}$ They promote conditions such as low levels of production and services, deepening economic crisis, lack of democratic traditions, and authoritarian forms of government.

What does it mean "to survive," "to adapt," "to exclude" and "to achieve" in modern Ukraine? I explain by using the ideas of Babenko ${ }^{55}$, a Ukrainian sociologist who studies social practices, life strategies and the mechanisms of post-communist societal transformations. The typology of life strategies suggested by Babenko has the best potential for the analysis of behavioral models in terms of the interrelation between the incidence of such models and the socioeconomic development in the country. This typology includes a continuum of behavioral strategies of social actors that includes the following nodal categories: achievement strategies, strategies of social adaptation, strategies of survival and strategies of social exclusion (isolation, withdrawal from social reality) and the relevant social practice. Such typology frames are the elements that fill these strategies with content. 
Table 1. Typology of life strategies by Svitlana S. Babenko in "Social Mechanism of Post-Soviet Transformation: Agency-Structural Perspective" 56

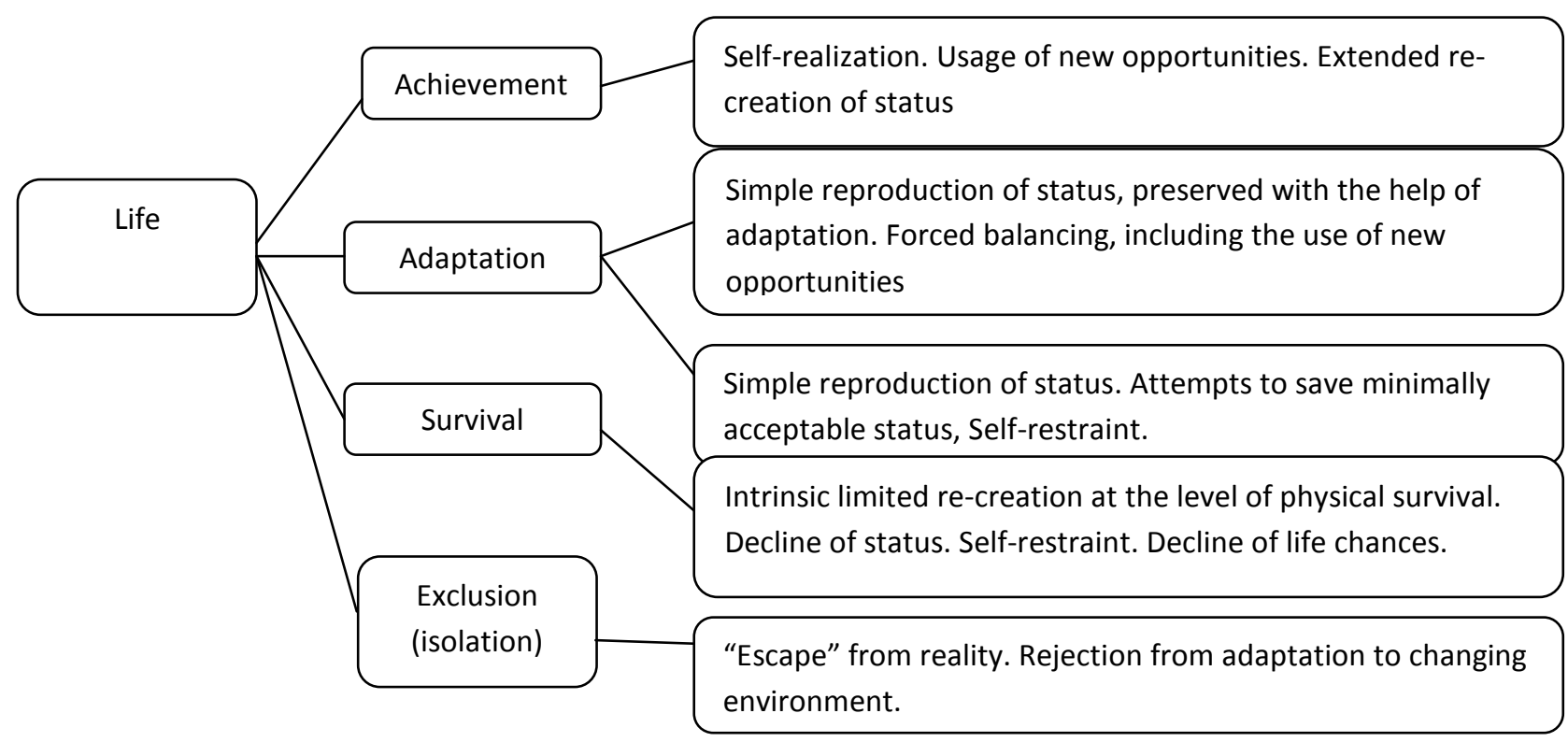

Babenko has distinguished four life strategy types (see Table 1.) based on the following criteria, which determine the strategy content: (1) the way of reproduction of social status (advanced, simple and truncated) and, therefore, decline or increase of life chances and opportunities; (2) the degree and quality of adaptation to changing conditions of social reality (successful, uncertain (unstable), failure (inability or refusal from adaptation)); (3) the level and quality of usage of new opportunities emerging in conditions of a rapidly changing social environment within the post-Soviet transformation processes.

The social structure of contemporary Ukrainian society seems to be a hybrid system of mutually penetrating types of social homogeneity and inequality as a result of the social changes during the last 22 years. There is a significant gap between social groups who have high life chances and groups whose life chances are very restricted by local opportunities (the major part of society). As a result, the present economic and social well-being of the majority of Ukrainians determines the choice to adopt exclusion, survival or adaptation life strategies, but not the achievement ones. Those values, attitudes and life strategies that are institutionalised in the society shape the limits of the change of the societal system. Yet it is only the achievement strategy which has been shown by several studies to be not relevant for the majority of Ukrainians that have a significant positive influence on the process of social change. Subsequently, depending on the "proportion" of these life strategy types within the society, the country follows a number of paths. The first is simple reproduction, the second declining reproduction or lastly dynamic changes. Therefore, the agency and agent's practices have the power to determine social and economic development of the country.

Hence, to determine the dynamics and direction of the modern social transformation becomes extremely important in order to clarify the strategic aspects of social practices of actors, namely correlation of strategies of achievement, patterns of adaptation and survival and the

${ }^{56}$ S.S. Babenko, 'Life Strategies and Social Practices: Sociocultural Potential of the Post-Soviet Society Transformation', Methodology, theory and practice of sociological analysis of society: a collection of scientific papers of Kharkov National University, 2002, p. 65. 
model of social exclusion (isolation). Hypothetically, if there is a high level of adaptive capacity in the society the transformation can be dynamic, and can even successfully implement reforms. More precisely, the existing adaptive capacity may indicate the tolerance and conformity of social actors to the reforms and accelerate the dynamic changes in the society. It is necessary to distinguish in which social structures and institutes such adaptive capacity is high: either the formal or informal. The merging of informal (shadow) and formal (institutional) structures in the modern Ukrainian society (as, indeed, in Russia and other post-Soviet societies) gives a mixed and complicated picture of transformation changes in relation to reforms. In situations of "dual institutionalization"57, when the new social institutions have not been created and the old ones are being replaced, terms of "stagnation," "low rates" and "inversion" become relevant. In this case, a high level of adaptive capacity within shadow (informal) institutions would reflect a process of inversion, the "turning" of reforms, and the filling of life strategies with a new content. In these circumstances an entirely different (new?) "parameters of structuration" will emerge, 58 eventually determining the structural and the functional characteristics of the society. Purportedly, high adaptation within the informal social sector can guide the development by the path of simple or declining reproduction in the society.

Given the 2012 data from the "Ukrainian Society: Monitoring of Social Change” the majority of Ukrainians follow the strategy of avoidance/ exclusion (escape from problems) (32\%), the second most widespread strategy is adaptation (27\%), and the least dominant strategy among Ukrainians is the strategy of mastering the situation (16\%). Further, a large percentage of Ukrainians draw on indefinite strategies that indicates their "lost" and "marginal" position in the society on the micro level, and the collective, faceless, passive mass on the macro level. This data signposts that in Ukrainian society there is a lack of agency and that the structural power over individual life still dominates. Moreover, the dominance of the strategy of exclusion in the society indicates there is no possibility of a successful completion of the transition. In such a society agency is practically absent. When there is no agency, there is no civil society. If there is no civil society, democracy will never be achieved. Consequently, when passive, pessimistic attitudes prevail among the population, indicating their rejection to adapt to changing environment, the spread of anomie is promoted. However, I cannot not mention that the number of Ukrainians who actively and successfully adapt to a new life and those who believe market conditions are a natural way of life has doubled between 1997 and 2012. This positive trend supports the contention that the prevalence of achievement and adaptation strategies types within the society is determined by the level of socio-economic and cultural development in the country, including the mode of production, the level and quality of life, the existence of the legal regulation of social life, the degree of participation in government, the influence of traditions, ideals and beliefs. This suggests that Ukrainian society still has hopes for a better, democratic life by means of dynamic social change.

\section{Conclusion}

It is hardly necessary to prove that today Ukraine is no more than halfway through the transformation process. The outcomes of transformation today can be defined as a "clan liberalization" of the economy and the "bureaucratic democratization" of society. Almost all social scientists, journalists and politicians would agree that this has brought with it a lot

${ }^{57}$ E.I. Golovakha and N. Panina, 'Main Milestones and Trends in Transformation of Ukrainian Society: from the "perebydova” to the "Orange Revolution,"' Sociology: Theory, Methods, Marketing, No. 3, 2006, pp. 32-51. 58 A. Giddens, The Constitution of Society. Outline of the Theory of Structuration, Cambridge, Polity, 1984. 
Oleinikova ANZJ ES 5(2)

more disappointments than achievements to Ukrainians. The estimates of modern dynamic trends are less than univocal. Some argue that the Ukrainian economy (and later the society) continues to slide lower and lower, while others continue to emphasise the first signs of an incipient turn for the better.

This article opens up the debate about the relationship and mutual interdependence between life strategies of individuals and social transformations reflecting the interrelationship between agency and structure. Particularly it argues that the proliferation of life strategy can determine the developmental trajectory of the whole society, giving insight into the circular relationship between social transformations and actions of individuals in conditions of social change, with an emphasise on the role of agents in the transformation processes. By life strategy within post-Soviet transition context I mean the rational organization of life as a response to social circumstances (e.g. survival, exclusion or adaptation), rather than the purely deliberate way of planning lives by individuals.

The data from the annual social research project "Ukrainian Society: Monitoring of Social Change" conducted in 2012 by the Institute of Sociology in Ukraine demonstrates that the strategy of avoidance/ exclusion is the most frequent life trajectory performed by $32 \%$ of Ukrainians. Such a figure suggests that in Ukrainian society there is a lack of agency, where actors actively approach social changes, therefore civil society has shown to be underdeveloped in Ukraine. Moreover, the data from the monitoring draws on agency as one that can gain two different forms of passive and active actors' responses to social change. Structural issues lead individuals to take up passive strategies rather than active ones and, thus, agency appears to be harder to enact in the transition stance. This indicates a slight failure of imported Western democracy in the post-Soviet Ukraine. However, the constantly growing number of people applying, mastering and taking up adaptive strategies in Ukraine still leaves room for the hope for the successful completion of democratic reform.

Applying the structure-agency perspective to the life strategies of Ukrainians, the concept of life strategy can be understood as a term describing a sequence of stages and transitions that are culturally and institutionally framed. More specifically, by focusing on the variety of ways scholars in this field have conceptualised and interpreted the idea, life strategies can be described as: 1) life strategies that are built on the basis of social actors, life representations, goals and aspirations of a personal, group, structural and institutional nature, 2) life strategies that represent only trends due to various conduct election lines, activities, social practices, and 3) life strategies as ways of spatial-temporal specification and coordination of purposes, ways, means, rates, procedures of movement to the target. Within the Ukrainian context, the notion of life strategy is gaining a rationalised character, guiding peoples' everyday practices by long-term goals aimed at adequate representations in the form of a response to changing social circumstances. However, in the modern post-Soviet transformation studies a common conceptual language that would allow for describing adequately the typical forms of life strategies at the micro and macro level of social analysis have not yet been developed.

For today, the relationship between the vector of socio-economic transformations and life strategies of individuals is not a well-researched issue. What is more important is that since the 1980s in the West and in post-Soviet Eastern European transition research scholarship the power of agency has been underestimated. Up-to-date publications on capitalist and democratic transition in Ukraine in combination with survey data give evidence that the processes of adaptation and resistance of the people involved play a significant role in the 
contemporary transformations of post-Soviet space. Given the current situation in Ukraine it becomes obvious that one of the most important challenges facing scholars today is to identify and monitor the dynamics of goals, values, attitudes, strategies and social practices of different population groups within transformation processes, as well as to characterise the possibilities and limits of institutional change and their enhancement within global processes and local specificity. 